\title{
Judicial Misconduct and Politics in the Federal System: A Proposal for Revising the Judicial Councils Act
}

The United States Constitution implies that a federal judge may be removed fron office only by the constitutionally mandated method of impeachnient. Article II, section 4 provides that civil officers may be impeached only for "Treason, Bribery, or other high Crimes and Misdemeanors." Article III, section 1 specifically provides that judges "shall hold their Offices during good behavior."2 While the first of these provisions creates the sole constitutional mechanism for impeaching federal officials, the second arguably suggests a broader standard of review in the case of federal judges.

In 1980, Congress passed the Judicial Councils Reform and Judicial Conduct and Disability Act of 1980 (the "Act"). ${ }^{3}$ The Act created a nrechanism short of impeachment for discipliming federal judges. This Comnent focuses on the role that politics can play in disciplining federal judges under the Act. This Comment criticizes the Act for its potential for use as a means of compromising the political independence of judges, and argues that judges should not be scrutinized by their colleagues for their politics.

In recent years, judicial discipline has become highly politicized, and federal judges are beconing more sensitive to the political climates surrounding their courts. Two controversial federal district court judges have been brought before investigatory comnittees, comprised of colleagues fron their own judicial districts, under the Act. ${ }^{4}$ Former District Court Judge Miles Lord and District Court Judge Alcee Hastings are both well-known for their outspoken political beliefs. ${ }^{5}$ Their censure

1. U.S. ConsT. art. II, $\$ 4$.

2. Id. at art. III, $\S 1$.

3. Pub. L. No. $96-458,94$ Stat. 2035 (1980) (codified as amended at 28 U.S.C. $\S \S 331,332$, 372, 604 (1982 \& Supp. III 1985)).

4. Miles Lord, former chief judge of the U.S. District Court for Minnesota, was brought before a five-judge investigatory committee because of remarks he made while presiding over a suit against A.H. Robins Co., the manufacturer of the Dalkon Shield intrauterine device. Alcee Hastings was brought before a five-judge investigatory panel because he allegedly accepted a bribe while sitting as district court judge in the Southern District of Florida.

5. Judge Lord has been described as a "representative of the poor and the undefended," and is widely regarded for his intensely populist streak, which has often placed him at the center of controversy. Ranii, A Judge's Public Battles, Nat'l L.J., July 23, 1984, at 1, col. 3. Judge Hastings 
exemplifies the recent use of the Act to scrutinize political beliefs in deciding questions concerning the fitness of particular federal judges.

Part I of this Comment explores the relationship that has historically held between politics and the federal judiciary. Part II describes the Act and discusses the cases of the two judges, Alcee Hastings and Miles Lord, against whom it has been invoked. Part III criticizes the Act in its current form on the grounds that it (1) authorizes the de facto removal of federal judges; (2) thwarts the Framers' intent that Congress should have the sole power to remove federal judges; (3) threatens judicial independence by subjecting judges to attack for politically unpopular decisions; and (4) subverts the constitutional process of impeachment. Part IV proposes a Revised Act that better balances the need to control judicial misconduct with the need to preserve judicial independence. The Comment concludes that in order to maintain the independence necessary for federal judges to properly interpret the law, ${ }^{6}$ the consideration of politics ${ }^{7}$ must be excluded from the inquiry in cases of judicial discipline.

\section{I}

\section{The Relationship Between Politics AND FEDERAL JUDGES}

Federal judges generally avoid public political activity while on the bench. They are popularly perceived as living a cloistered existence at a remove from the world of politics. One observer has aptly described the "traditional public image" of the federal judge as a cloistered, apolitical figure:

The justices are regarded as members of a monastic order, totally unconcerned with politics after donning their black robes. They exercise only the formal powers of selecting and deciding cases, construing statutes, and determining the constitutionality of legislative and executive actions. The image of a cloistered Court is sustained by a widely held conception that the constitutional separation of powers prohibits members of the judicial branch from exercising or influencing functions delegated to the

has been particularly controversial as an outspoken critic of the Reagan administration. Lauter, Hastings Challenge to Judicial Probe Rejected, Nat'l L.J., Aug. 6, 1984, at 11, col. 1.

6. See generally Kaufman, The Essence of Judicial Independence, 80 CoLuM. L. REV. 671 (1980) (criticizing the Act in light of historical and constitutional commitment to an independent judiciary); Kaufman, Chilling Judicial Independence, 88 YALE L.J. 681 (1979) [hereinafter Chilling Judicial Independence] (arguing that judicial independence is essential to democracy); Note, Indictment of Federal Judges: Chilling Judicial Independence, 35 U. FLA. L. REV. 296 (1983) (opposing criminal indictments of judges prior to impeachment).

7. In the context of this Comment, "politics" refers to conduct prolibited by Canon 7 of the CODE OF JUDICIAL CONDUCT (1972), such as leading or holding office in a political organization and making speeches or publicly endorsing a candidate for political office. 
other branches. ${ }^{8}$

Federal jurists thus confront a paradox regarding their political beliefs. Appointment to the federal bench is a highly politicized process. A person is appointed to the federal bench by the President, to whose political party the appointee in most cases belongs. But once appointed, judges are then required to refrain from extra-judicial activities-including politics-that might detract from the judiciary's appearance of absolute impartiality. ${ }^{9}$ Ironically, then, judges must refrain from the very activities that were probably in part responsible for their appointments.

Simce federal judges appear caught in this paradox, the effectiveness of the judiciary depends partly on balancing politics and impartiality. As Justice Fortas observed, a member of the federal judiciary cannot completely remove himself from the world of politics. ${ }^{10}$ Yet the deinand of impartiality does justify limits on the political activity of the judiciary.

Despite the public perception of a cloistered bench, many federal judges do not resist the lure of political life. The history of the federal judiciary mcludes many examples of politically active judges. These examples suggest that it is possible to maintain some balance between the control of judicial misconduct and the pohtical independence of the judiciary.

As early as 1790, Chief Justice John Jay and Associate Justice Ohiver Ellsworth stepped outside their judicial capacities to represent the United States in treaty negotiations with England and France. ${ }^{11}$ In 1817, Justice Joseph Story relied on Congressinan Daniel Webster to promote bills he favored dealing with the judiciary and bankruptcy. ${ }^{12}$ Two years later, Chief Justice John Marshall wrote a series of anonymous newspaper essays defending the Supreine Court's decision in $\mathrm{McCulloch} v$. Maryland. ${ }^{13}$ Before the Civil War, Justice John McLean repeatedly sought the Presidential nomination from the Supreme Court bench. ${ }^{14}$ In 1857, Justice John Catron and Robert Grier revealed to President-elect James Buchanan the contents of the Dred Scott decision before its publi-

8. Murphy, Elements of Extrajudicial Strategy: A Look at the Political Roles of Justices Brandeis and Frankfurter, 69 GEO. L.J. 101, 101 (1980).

9. See CODE of Judicial Conduct Canon 7 (1972).

10. See Murphy supra note 8, at 103 (quoting Nominations of Abe Fortas and Holner Thronberry: Hearings Before Senate Comm. on the Judiciary, 90th Cong., 2d Sess. 228 (1968)).

11. See W. Brown, The Life of Oliver Ellsworth 215, 277 (1905).

12. See G. DUNNe, Justice Joseph STORY AND the Rise OF THE SUPREME Court 161-64 (1970).

13. 17 U.S. (4 Wheat.) 316 (1819). See John Marshall's Defense of McCulloch v. Maryland 78, 155 (G. Gunther ed. 1972). The essays appeared in the Philadelphia Union between April 24 and April 28, 1819, and in the Alexandria Gazette between June 30 and July 15, 1819.

14. See F. Weisendurger, The Life of John McLean: A Politician on the United STATES SUPREME COURT 68-80, 103-05 (1937). 
cation. ${ }^{15}$ Chief Justice William Howard Taft played an active role in selecting federal judges during President Harding's administration. ${ }^{16}$ As recently as 1963, Chief Justice Earl Warren chaired the commission that investigated the assassination of President John F. Kennedy. ${ }^{17}$

Justices Brandeis and Frankfurter exemplify the direct role that federal judges have played in politics. Although Justice Brandeis was a proponent of the traditional nonpolitical image of federal judges, he was politically active during his years on the Court. ${ }^{18}$ Brandeis was the principal developer of President Woodrow Wilson's New Freedom Platform, and as such played a major role in creating both the Federal Reserve System and the Federal Trade Commission, and in passing the Clayton Anti-Trust Act. ${ }^{19}$ Brandeis paid Frankfurter, then a politically active Harvard law professor, to lobby for social change on Brandeis' behalf. ${ }^{20}$ Brandeis also called on other influential political allies, including Justice Harlan Fisk Stone, editor Norman Hapgood, New Deal architect Raymond Morley, Secretary of the Navy Josephus Daniels, and Secretary of the Treasury Williain McAdoo, to influence public policy as Brandeis wished. ${ }^{21}$ On occasion, Brandeis even conferred directly with Presidents Wilson and Roosevelt. 22

In contrast to the advisory role Brandeis used to advance his political beliefs, Frankfurter lobbied actively for social reforms even after his appointment to the Supreme Court. Frankfurter's friendship with President Franklin D. Roosevelt put him squarely in the middle of many of the President's most important policy decisions. During World War II, Frankfurter conferred almost daily with Roosevelt about strategies and policies, and assisted Roosevelt in preparing some of his speeches. ${ }^{23}$ In 1940, Frankfurter was instrumental in securing for his former mentor, Henry L. Stinson, the position of Secretary of War under Roosevelt. ${ }^{24}$ Frankfurter was also active in Roosevelt's 1940 election campaign against Wendell Willkie. ${ }^{25}$

Justice Abe Fortas and Chief Justice Warren Burger also engaged in

15. See C. SWISHER, Roger B. TANeY 498-500 (1935).

16. See Murphy, Chief Justice Taft and the Lower Court Bureaucracy: A Study in Judicial Administration, 24 J. PoL. 453, $459-61$ (1962); Murphy, In His Own Image: Mr. Chief Justice Taft and Supreme Court Appointments, 1961 SuP. CT. REv. 159, 161-63.

17. See E. Warren, The Memoirs Of Earl Warren 350-72 (1977).

18. See Murphy, supra note 8, at 111.

19. Id. at 110 .

20. Id. at 111-14.

21. See 5 LetTers of Louis D. Brandeis 371-72, 552-53 (M. Urofsky \& D. Levy eds. 1978); 4 id. at 293 (1975); 2 id. at 663 n.1 (1972); A. MASON, BRANDEIS: A FREE MAN's LifE 519 (1946).

22. See A. MASON, supra note 21, at 521-22, 635 .

23. See Murphy, supra note 8, at 115,120 (citing RoOsevelt and FrankfurTer: THEIR CORRESPONDENCE, 1928-45, at 10-11 (M. Freedman ed. 1967)); id. at 119-20.

24. See id. at 116.

25. See id. at $119-20$. 
political activity while seated on the Court, though they received more public criticism for doing so. Justice Fortas enjoyed a close relationship with President Lyndon Johnson. Johnson and Fortas often conferred on a variety of political subjects even after Johnson appointed Fortas to the Supreme Court. While Fortas was a Supreme Court Justice, he advised Johnson on topics including the Vietnam War, steel price increases, and strategy for averting transportation strikes. ${ }^{26}$ As a result, Republicans and Democrats alike assailed Johnson's nomination of Fortas for the Chief Justice position. They accused Fortas of lacking judicial propriety because of his ongoing advisory relationship with President Johnson. These criticisms of Fortas eventually led to his resignation from the Court, but as Fortas astutely observed, even a member of the Supreme Court can hardly avoid discussing political issues:

I don't know how anybody can be a person and not discuss with his friends these days questions about the budget and about the Vietnam war. I'm a person, too. I am a Supreme Court justice, but I talk to people, and people talk to me. I don't see how you can avoid discussing questions like that. ${ }^{27}$

Former Chief Justice Warren Burger was also criticized for his political activities wliile on the bencli. In 1978, Burger was so dissatisfied with Congress's proposed revision of federal bankruptcy laws that lie urged Senator Strom Tliurmond to put a "liold" on the bill. ${ }^{28}$ Senate Majority Leader Robert Byrd criticized the Chief Justice for this "inappropriate" intervention into the legislative process. ${ }^{29}$ Burger however, believed that the Chief Justice should be able to comment on bills pending in Congress:

[T] he separation of powers concept was never remotely intended to preclude cooperation, coordination, communication and joint efforts by members of each branch with members of the others. ... If the Judges, whose lives are devoted to these problems, are not qualified to advise on such matters, one may well ask "who is. ..."30

All of these judges were active in politics during their tenures on the federal bencli, yet no removal proceedings were ever instituted against any of them. Sliould a federal judge be subject to removal for his or lier political activities?

A litigant cannot expect that the inind of a federal judge will be a

26. Id. at 102 (citing Graham, The Many-Sided Justice Fortas, N.Y. Times, June 4, 1967, § 6 (Magazine), at 94).

27. See Murphy, supra note 8, at 103 (quoting Nominations of Abe Fortas and Horner Thomberry: Hearings Before Senate Comm. on the Judiciary, 90th Cong., 2d Sess. 228 (1968)).

28. See id. (citing 36 Cong. Q. 2969 (Oct. 14, 1978)).

29. See id.

30. Id. at 104 (quoting W. Burger, Address at the Fordham-Stein Award Dinner (Oct. 25, 1978)). 
complete tabula rasa with respect to political issues. ${ }^{31}$ A federal judge cannot remain politically blind when confronted with cases involving inherently political issues, such as affirmative action or government funding for abortions. But a judge should approach with an open mind the legal positions a litigant advances. A litigant is certainly entitled to a judge who is not actively lobbying for a position opposed to the litigant's interest. When federal judges involve themselves in such active lobbying, the appearance of impartiality is destroyed and the judiciary's effectiveness is undermined.

Accordingly, the political activities of judges must be restricted to the extent necessary to prevent them from distorting the proper functions of the legal system. But such restrictions must not foreclose the judicial independence of individual judges to inake politically unpopular decisions. As English Prime Minister Lord Salisbury observed: "The judicial salad requires both legal oil and political vinegar; but disastrous effects will follow if due proportion is not observed." ${ }^{32}$

II

The Judicial Councils Act and Its Potential FOR ABUSE

The difficult task of balancing the conflicting goals of judicial independence and effective policing of the federal judiciary requires a disciplinary mechanism that protects the political independence of federal judges. In 1980, Congress attempted to create such a mechanism by passing the Judicial Councils Reform and Judicial Conduct and Disability Act (the "Act"). ${ }^{33}$

The Act prompted a controversy between those who advocate an efficient, streamlined method for disciplining federal judges and those who argue that impeachment pursuant to article III is the only constitutionally permissible means of discipline. ${ }^{34}$ At the heart of this controversy is the issue of whether the Act is constitutional in light of article III's impeachment provision. A not unrelated issue is the Act's potential for abuse when it is used against judges whose political ideologies are unpopular with their colleagues.

31. See Nathanson, The Extra-Judicial Activities of Supreme Court Justices: Where Should the Line Be Drawn? (Book Review), 78 Nw. U.L. Rev. 494, 523 (1983).

32. Jones, Should Judges Be Politicians?: The English Experience, 57 IND. L.J. 211, 213 (1982) (quoting R.F.V. HeUsTON, LIVES OF THE LORD CHANCELlORS 57 (1964)).

33. Pub. L. No. $96-458,94$ Stat. 2035 (1980) (codified as amended at 28 U.S.C. $\S \S 331,332$, 372, 604 (1982 \& Supp. III 1985)).

34. See infra notes 60-61. 


\section{A. A Description of the Act}

The Act details the process whereby a federal judge who is accused of malfeasance may be brought before a panel of judges to answer to charges leveled against her. It provides that:

Any person alleging that a circuit, district, or bankruptcy judge, or a magistrate, has engaged in conduct prejudicial to the effective and expeditious administration of the business of the courts . . . may file with the clerk of the court of appeals for the circuit a written complaint containing a brief statement of the facts constituting such conduct. ${ }^{35}$

Two facets of the filing procedure warrant close examination. First, any person may file a complaint against a judge. The Act contains no standing requirement because a complaint under the Act is not an article III "case" or "controversy." 36 Rather, it is an internal administrative procedure, a form of judicial self-monitoring. ${ }^{37}$ Such proceedings "are the concern of the judicial council, not the court."38 Consequently, anyone could conceivably bring a complaint under the Act, regardless of injury, causation, or redressability. ${ }^{39}$ Anyone who merely disagrees with a judge can initiate a section 372 (c) action as long as he alleges the prejudicial conduct required by the statute. ${ }^{40}$

Second, it is unclear what allegations of misconduct are necessary to meet the prejudicial conduct standard of the Act. The standard apparently includes any behavior that affects the "effective and expeditious administration" of a court. Nevertheless, one federal district court has expressly upheld the constitutionality of the Act in the face of a vagueness challenge. In Hastings v. Judicial Conference of the United States, ${ }^{41}$

35. 28 U.S.C. $\S 372$ (c)(1) (1982).

36. U.S. CoNST. art. III, $\S 2$, cl. 1; see In re Martin-Trigona, 737 F.2d 1254, 1263 (2d Cir. 1984). The standing determination has two prongs, one constitutional and the other prudential. The Constitution requires a plaintiff to allege a personal injury (injury in fact) that is both fairly traceable to defendant's conduct (causation) and likely to be redressed by the requested judicial action (redressability). Allen v. Wright, 468 U.S. 737, 750-52 (1984). The prudential prong also has three primary considerations: (1) the general prohibition against one litigant raising the rights of another; (2) the rule barring adjudication of generalized grievances more appropriately addressed to another branch of government; and (3) the requirement that plaintiff's complaint fall within the zone of interests sought to be protected by the law invoked. Id. at 751.

37. Martin-Trigona, 737 F.2d at 1261.

38. Bergen v. Edenfield, 701 F.2d 906, 909 (11th Cir.), cert. denied, 464 U.S. 845 (1983).

39. But see Martin-Trigona, 737 F.2d at 1263 (suggesting that a party could be enjoined from using the section 372 (c) process upon finding an abuse of that process which impairs the administration of justice).

40. Of course, merely because a litigant is dissatisfied with a judge's opinion does not entitle her to raise issues based on the merits of her case in a section 372(c) proceeding. 28 U.S.C. $\S 372$ (c)(3)(A) (1982); see also In re Charge of Judicial Misconduct, 691 F.2d 924, 925 (9th Cir. 1982) (denying section 372 (c) relief when other judicial remedies are available to disgruntled litigant).

41. 593 F. Supp. 1371, 1382-83 (D.D.C. 1984), vacated, 770 F.2d 1093 (D.C. Cir. 1985) (case not ripe for decision on constitutionality of statute), cert. denied, $106 \mathrm{~S}$. Ct. 3272 (1986). 
the court held that "prejudicial conduct" meant a "clearly established pattern" of unethical conduct. ${ }^{42}$ According to the court, one or two isolated instances of possibly unethical behavior would not meet the standard unless they were so inappropriate as to amount to an impeachable offense. $^{43}$

Upon a proper filing, the chief judge of the circuit court reviews the complaint. The chief judge may dismiss the complaint if it does not allege conduct she deems prejudicial to the effective administration of the business of the courts, if it is "frivolous," or if it is "directly related to the merits of a decision or procedural ruling." 44 The chief judge has the discretion to interpret the bounds of the prejudicial conduct standard in deciding whether or not to dismiss the complaint. Even if the complaint falls squarely into one of these categories, the chief judge is not compelled to dismiss at this stage.

If the chief judge decides not to dismiss the complaint at the preliminary stage, she may proceed in one of two ways. She must either "conclude the proceeding if [s] he finds that appropriate corrective action has been taken," ${ }^{45}$ or appoint a special committee consisting of herself and other members of the circuit (including both district and circuit judges) to investigate the complaint and to file a written report of findings and recommendations with the judicial council of the circuit. ${ }^{46}$

Once a report is filed, the judicial council may "conduct any additional investigation which it considers to be necessary." 47 The council is then instrncted to "take such action as is appropriate." 48 The Act lists seven possible actions to illustrate, but not to limit, the power of the judicial council. Perhaps the most severe action is that the council may order that no new cases be assigned to the judge under investigation "on a temporary basis for a time certain." 49 The judicial council also has the option of referring the complaint to the Judicial Conference of the United States. ${ }^{50}$ If it determines that the judge's conduct "might constitute" grounds for constitutional impeachment, ${ }^{51}$ or "in the interest of justice, is not amenable to resolution by the judicial council,"52 the judicial council must certify such a determination to the Judicial

\footnotetext{
42. Id. at 1382 .

43. Id.

44. 28 U.S.C. $\S 372(\mathrm{c})(3)(\mathrm{A})(1982)$.

45. Id. $\S 372(\mathrm{c})(3)(\mathrm{B})$.

46. Id. \& 372(c)(4)-(5).

47. Id. $\S 372(\mathrm{c})(6)(\mathrm{A})$ (1982 \& Supp. III 1985).

48. Id. $\S 372(\mathrm{c})(6)(\mathrm{B})$.

49. Id. § 372(c)(6)(B)(iv).

50. Id. $\S 372(\mathrm{c})(7)(\mathrm{A})(1982)$.

51. Id. \& 372(c)(7)(B)(i).

52. Id. $\S 372(\mathrm{c})(7)(\mathrm{B})(\mathrm{ii})$.
} 
Conference. ${ }^{53}$

The Judicial Conference may conduct further investigation of any certified complaint. ${ }^{54}$ It may impose the same types of disciplinary action as the judicial council, including barring further cases from the judge's docket. ${ }^{55}$ If the Judicial Conference determines that "consideration of impeachment may be warranted," it must send that finding and the record of the proceedings to the House of Representatives. ${ }^{56}$

A judge against whom such proceedings have been brought may petition the judicial council for a review of the order by the chief judge. The aggrieved judge may also petition the Judicial Conference for a review of the action of the judicial council. ${ }^{57}$ All Judicial Conference determinations including denial of petitions for review, are final and not subject to judicial appeal. ${ }^{58}$ Indeed, all determinations under the Act are nonreviewable.

The Act grants wide discretion to chief judges, judicial councils, and the Judicial Conference in disciplining federal judges. The reach of its provisions poses the crucial question of whether it unconstitutionally infringes on either the limits placed on the causes for impeachment under article II and the judge's right to tenure under article III. ${ }^{59}$ No court has yet ruled on the constitutionality of imposing the range of sanctions allowed by the Act. ${ }^{60}$ Until the Supreme Court reviews and defines the powers of these essentially administrative review councils, the controversy will continue between those who advocate streamlined discipline for federal judges and those who advocate restricting judicial discipline to impeachment under article II. ${ }^{61}$

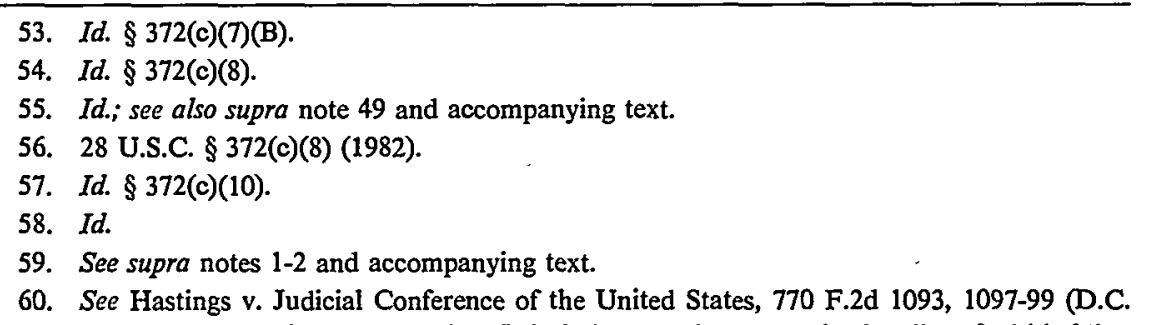
Cir. 1985), cert. denied, 106 S. Ct. 3272 (1986) (refusing to rule on constitutionality of withholding assignment of cases to judge under investigation or of vagueness of prejudicial conduct standard because such rulings would be "premature"). In 1970, the Supreme Court also declined to rule on the constitutionality of a predecessor to the Judicial Councils Act. In that case, the accused judge argued that the Act "usurped the impeachment power" granted to Congress under article I. Chandler v. Judicial Council of the Tenth Circuit, 398 U.S. 74, 82, 86 (1970).

61. Compare James Madison's statement, "the judges are to be removed only on impeachment, and conviction before Congress," 11 ANNALS OF CoNG. 738 (1802) (quoted by Rep. Rutledge of S.C., Feb. 24, 1802), with Congress' view in 1980 that "the impeachment process has become unduly cumbersome and ineffective" and that some form of discipline was needed "to fill the void which currently exists in the law between the impeachable offenses and doing nothing at all." S. REP. No. 362, 96th Cong., 1st Sess. at 4-5 (1979), reprinted in 1980 U.S. CODE CONG. \& ADMIN. NEws 4315, 4318. 


\section{B. Potential Abuse of the Act: The Cases of Miles Lord and Alcee Hastings}

Besides these possible constitutional infirmities, the Act has a dangerous potential for abuse. Its procedures couple a complete lack of standing requirements with broad judicial discretion. Conceivably, a complainant can file a meritless complaint against a federal judge with whom she has little or no contact. With the broad discretion imparted by the Act, such a complaint might provoke a full-scale investigation and, allowing for error and prejudice, even result in unfair disciplinary action. This scenario is perhaps most likely in cases involving a judge with an unpopular political ideology.

Former District Court Judge Miles Lord ${ }^{62}$ and District Court Judge Alcee Hastings ${ }^{63}$ have both felt the impact of the Act. Both have been investigated pursuant to the Act, and both have suffered damage to their careers and reputations as a result of the investigative procedures the Act authorizes. An examination of the Act's effect on the careers of these two judges illustrates its potential for abuse.

Miles Lord is the type of judge most likely to be investigated under the provisions of the Act. Although Judge Lord's career is distinguished by a thirty-year commitment to public service in Minnesota, ${ }^{64}$ his judicial activism has often placed him at the center of controversy, ${ }^{65}$ making him a very visible target.

In 1984, Lord's outspokenness proved particularly controversial. Judge Lord presided over a trial concerning the safety of the Dalkon Shield intrauterine device, manufactured by the A.H. Robins Company. ${ }^{66}$ Five days after the parties to this lawsuit entered into a settle-

62. Miles Lord served on the U.S. District Court for the District of Minnesota between 1966 and 1985. During the years 1981 through 1985, Judge Lord held the position of chief judge of the District Court in Minnesota. Judge Lord retired from the bench in September 1985 to pursue private practice with the Minneapolis law firm of Grose, Von Holtum, Sieben \& Schmidt. Cook, Still Outspoken, NAT'L L.J., Aug. 18, 1986, at 2, col. 1.

63. Alcee Hastings was appointed to the U.S. District Court for the Southern District of Florida by President Jimmy Carter in 1979. Hastings has served continuousiy on the federal bench since his appointment. Friend, Peer Pressure, AM. LAw., Nov. 1986, at 83, col. 2.

64. Prior to his appointment to the federal bench Lord had served as U.S. Attorney (1960-66), Attorney General for the state of Minnesota (1954 to 1960), and as Assistant United States Attorney (1951-52). Articles by Judge Miles W. Lord-Introduction, 9 HamLine L. REV. 3, 3 (1986).

65. See, e.g., Sierra Club v. Clark, 607 F. Supp. 737 (D. Minn. 1985) (ordering Interior Department to prohibit wolf trapping in Northern Minnesota); National Ass'n of Property Owners v. United States, 499 F. Supp. 1223 (D. Minn. 1980) (upholding authority of Secretary of Agriculture to ban motorboats in the Boundary Waters Canoe Area), aff'd sub nom. Minnesota v. Black, 660 F.2d 1240 (8th Cir. 1981), cert. denied, 455 U.S. 1007 (1982); United States v. Reserve Mining Co., 380 F. Supp. 11 (D. Minn. 1974) (issuing temporary injunction curtailing release of mining byproducts into Lake Superior), modified and remanded sub nom. Reserve Mining Co. v. EPA, 514 F.2d 472 (8th Cir. 1975).

66. Gardiner v. A.H. Robins Co., Civil Nos. 84-5061-MN; 84-5062-MN (1984). 
ment agreement, Judge Lord reprimanded the corporate officers of Robins for their irresponsible behavior in selling the Dalkon Shield. ${ }^{67}$ Three of the A.H. Robins officers named in the reprimand filed a complaint under the Act, charging that Judge Lord's behavior was "bringing the courts into disrepute and prejudicing the administration of justice." 68 The judicial council of the Eighth Circuit then began proceedings under the Act against Judge Lord. ${ }^{69}$ A five-judge panel spent seven months investigating the allegations against Judge Lord. In December 1984, following the recommendation of that investigative panel, the judicial council dismissed the complaint. ${ }^{70}$

Although the charges against Judge Lord were ultimately dismissed, the investigation itself affected him and damaged his reputation. The fact that he was exonerated does not compensate for the psychological and financial hardship he endured during those proceedings. A lifelong public servant, Judge Lord was hardly a rich man, yet it cost him over $\$ 70,000$ in legal fees to defend against this single complaint. ${ }^{71}$ Perhaps even more damaging than the financial cost was the psychological hardship. Judge Lord asserted that the proceedings under the Act made him "feel like a criminal": "It reflects on your career, personality and fainily in a way that having a decision reversed cannot."72 The ultimate result of this proceeding was that Judge Lord retired froin the judiciary to pursue private practice nine months after the dismissal of the complaint. ${ }^{73}$

The ordeal of Judge Alcee Hastings presents another danger inherent in the Act-the risk that a politically unpopular judge can be constructively removed from office. Judge Hastings is a particularly outspoken, controversial judge who was unpopular with his colleagues on the Eleventh Circuit. ${ }^{74}$ In 1981, he was indicted for conspiring to take a bribe from William Borders, who was an attorney and long-time

67. Judge Lord stated, "Gentlemen, the result of these activities and attitudes on your part have been catastrophic. ... None of you have faced up to the fact that more than 9,000 women have made claims that they gave a part of their womanhood so that your company might prosper." The Dalkon Shield Litigation: Revised Annotated Reprimand By Chief Judge Miles W. Lord, 9 HAmLINE L. REv. 7, 8-9 (1986) (editor's note). Judge Lord went on to state, "Under your direction your company has in fact continued to allow women, tens of thousands of them, to wear this device, a deadly depth charge in their wombs, ready to explode at any time." Id. at 10.

68. Complaint at 3 (back of page), In re Complaint of Judicial Misconduct by $\mathrm{E}$. Claiborne Robins, Jr., JCP 84-002 (8th Cir. Apr. 24, 1984).

69. Note, Unnecessary and Improper: The Judicial Councils Reform and Judicial Conduct and Disability Act of 1980, 94 YALE L.J. 1117, 1142 (1985).

70. Id.

71. Id.

72. Id.

73. Cook, supra note 62 , at 2 , col. 1 .

74. Judge Hastings characterizes President Ronald Reagan as a "racist and a liar." Friend, supra note 63 , at 82 , col. 2. As to the collegiality that exists between himself and Judges Hodges, Alaimo, and Godbold of the Eleventh Circuit, Hastings fiatly asserts, "Hell no, I don't like them, and hell no, they don't like me." Id. 
friend. The charge stemmed from a 1980 case in which two defendants were convicted of twenty-one counts of racketeering and ordered to forfeit $\$ 1.2$ million in property under the forfeiture provision of the Racketeer Influenced Corrupt Organizations Act. ${ }^{75}$ The allegation against Judge Hastings charged him with conspiring with Borders to obtain the release of the defendants' property in return for payment of $\$ 150,000$. In early 1983, a jury acquitted Judge Hastings of the criminal charges. ${ }^{76}$

In March 1983, only one month after he was acquitted of the criminal charges, two of Judge Hastings's fellow district court judges in the Eleventh Circuit filed a complaint against him under the Act. Unlike Judge Lord's case, the proceedings against Judge Hastings have dragged on for more than three years. ${ }^{77}$ The damage both to Hastings personally and to the court on which he sits has been immeasurable.

While Judge Hastings has remained a sitting judge during the investigatory proceedings, his status and effectiveness as a sitting judge have been affected by the investigation. One practitioner explains the effect of the charges pending against Judge Hastings: "I'll just appeal Hastings to the Eleventh Circuit because they may just help me out on him."78 Like Judge Lord, Judge Hastings is now considering leaving the federal bench because of the damage to his reputation. ${ }^{79}$

Even more alarming than the damage to these individual judges' careers is the message that the Act sends to other potentially controversial judges. Under the Act, any unpopular expression of judicial independence can incur the harshest consequences. For example, Judge Edwards, concurring in Hastings, recognized that " $[t]$ he provisions of the Act might be subject to abuse-that they might be misused to pressure or intimidate the nonconformist, the judge whose judicial style or legal philosophy are repugnant to the majority of his or her colleagues." commentator has expressed a similar concern: "the possibility of judicial removal for vague grounds of dissatisfaction would create a dragnet that would inevitably sweep into its grasp the maverick, the dissenter, the innovator, the reformer-in a word, the unpopular." 11

75. 18 U.S.C. $\& 1963$ (1982).

76. Friend, supra note 63 , at 81 , col. 4 .

77. Judge Hastings criticized the Act for trying him, in effect, for a crime for which he had aiready been acquitted. Judge Hastings stated: "It walks like double jeopardy, it talks like double jeopardy, it sounds like double jeopardy, it feels like double jeopardy." Id. at 82, col. 1. In addition, the judicial council has voted unanimously to certify the case to the judicial conferencc for possible referral to the House of Representatives for impeachment proceedings. Id. at 86, col. 2.

78. Id. at 87, col. 1.

79. $I d$.

80. Hastings v. Judicial Conference of the United States, 770 F.2d 1093, 1107 (D.C. Cir. 1985)

(Edwards, J., concurring).

81. Kaufman, Chilling Judicial Independence, supra note 6, at 703. 
III

\section{A Critique of the Judicial Councils Act}

\section{A. The Act Authorizes the De Facto Removal of Federal Judges}

The Act does not clearly specify any procedures for removing federal judges. It does, however, authorize de facto removal by empowering the judicial council to order that "on a temporary basis for a time certain no further cases be assigned" to a judge against whom a complaint is brought. $^{82}$ The accused judge retains all the trappings of a federal judge such as an office, law clerks, and salary. But since he is suspended from hearing cases, he is effectively removed from the most vital function of his position.

Judge Edwards made this point in the appeal of the Hastings case: At oral argument, the court attempted to ascertain whether the suspension provision contained any implicit time limits. When asked whether a judicial council could "temporarily" suspend a judge for fifteen years, counsel for the appellees unhesitatingly responded "yes." It seems to me that this suspension provision, both on its face and as interpreted by the appellees, poses extraordinarily troublesoine separation of powers and Impeachment Clause problems. ${ }^{83}$

Judge Edwards went on to state:

Suspension for a fifteen year period strikes me as being the functional equivalent of removal. Should effective removal be available through council and Conference proceedings, Congress would retain little incentive to put itself through the cumbersome, time-consuming and painful process of impeachment, which I believe the Framers intended to be the exclusive method of removing federal judges froin office. ${ }^{84}$

Judge Edwards thus correctly recognized that a procedure that circumvents the constitutionally mandated but cumbersome process of impeachment would inevitably render that process obsolete.

While the Act permits de facto reinoval, it does not offer a welldefined standard of judicial misconduct. Under the language of the Act, a federal judge inight be subject to the full sanctioning provisions of the Judicial Conference for any conduct the chief judge deems "prejudicial" to the effective operation of the federal courts. ${ }^{85}$ The Act does not define the term "prejudicial," nor does it allow for an appeal of the chief judge's decision.

The constitutional impeachment provisions of article II provide greater protection to judges and have less potential for abuse. To trigger inpeachment proceedings, a judge must be accused of "Treason, Bribery,

82. 28 U.S.C. § 372(c)(6)(B)(iv) (Supp. III 1985).

83. Hastings, 770 F.2d at 1108 (Edwards, J., concurring) (emphasis added).

84. Id. at 1109 (emphasis added).

85. See supra notes $41-43$ and accompanying text. 
or other High Crimes and Misdemeanors." This standard offers a more certain guideline to what constitutes behavior warranting discipline.

This Comment does not suggest the adoption of the article II standard into the Act. This standard applies only to the formal procedure of impeachment; judicial misconduct not covered by it would warrant discipline short of impeachment. But the current Act's "prejudicial conduct" standard is simply too vague and too susceptible of abuse. Accordingly, this Comment proposes a statutory standard less strict than the constitutional prohibitions, yet more certain than the prejudicial conduct standard of the current Act. ${ }^{86}$

\section{B. The Act Thwarts the Framers' Intent Because It Allows Federal Judges to Effectively Remove Other Federal Judges}

The Framers of the Constitution intended impeachment to be the most severe form of sanction for a federal judge. The Constitution exphicitly provides that the House of Representatives has the exclusive power to initiate the impeachment process. ${ }^{87}$ The Constitution also provides that the Senate should have the sole power to try a federal judge for such charges. ${ }^{88}$ The Framers did not state whether other methods could be used to sanction federal judges. ${ }^{89}$

The Act ignores the Framers' intent. It subjects a judge to the scrutiny of not only the House and the Senate, but also of the federal judiciary. In effect, a judge's colleagues try him for his alleged malfeasance. The Framers recognized that for a federal judge to have the freedom to render his or her opinions without fear of personal sanctions, a judge should not be made to answer to a body composed of his or her judicial colleagues.

The Framers were conscious that the power to sanction a judge for any form of insufficiency posed the greatest threat to her independence. Moreover, they recognized that the independence of the judicial branch could be ensured only if it were comprised of autonomous individuals,

86. See infra Part IV.

87. "The House of Representatives ... shall have the sole Power of Impeachment." U.S. Const. art. I, § 2, cl. 5 .

88. "The Senate shall have the sole Power to try all Impeachments." Id. art. I, § 3, el. 6.

89. "No express terms making impeachment the exclusive method of removal are contained in the Constitution. ... The fact that Congress has the sole right to bring and try impeachments does not answer the question whether there are other methods of removal." R. BERGER, IMPEACHMENT: The Constitutional Problems 36 (1973) (emphasis in original).

John Vining declared in the First Congress that impeachment is "insufficient to secure the public safety" and termed impeachment "circuitous," "dilatory and inefficient," and a procedure prone to "delays and uncertainties." Id. at 123 n.9. Elias Boudinot said in the First Congress: "It is nowhere said that officers shall be removed but by impeachment; but it says they shall be removed on impeachment." Id. at 138 n.73. 
each uncoerced in her exercise of the judicial power. ${ }^{90}$

The Framers actually considered and rejected an impeachment mechanism similar to the Act.

Although the Framers considered giving the power to try impeachments to the Supreme Court, or to a combination of the Supreme Court and the Senate, they concluded that the Senate must have "the sole Power to try all Impeachments." This decision to establish but one "court" for the trial of all impeachments was logically consistent with the Framers conception of impeachment as a single process ... to which a single type of person . . . was to be subjected for a single kind of offense . . . ${ }^{91}$

The Framers chose the Senate to try impeachment cases both because of their confidence in the Senate's impartiality and because of their belief that its large membership would assure justice and "public tranquility."92 The Act thus subverts the Framers' intent because it allows for the de facto removal of a federal judge by other federal judges without the constitutional safeguards that the Framers intended.

\section{The Act Threatens Judicial Independence by Subjecting Judges to Reprisal for Politically Unpopular Decisions}

Besides subverting the Constitution, the Act has a chilling effect on the independence of individual judges. A judge in a controversial case should be able to make a politically unpopular decision, free from outside pressure. Members of the federal bench must be able to offer controversial solutions to difficult issues without fear of political reprisal. If a judge can be made to answer for any allegations of impropriety, and his colleagues have the power to take his cases away, then his position can be placed in jeopardy merely because he is politically unpopular. ${ }^{93}$

Judicial independence is essential to a judge's role as a decisionmaker. Each judge has a unique inethod for deciding cases, and each should be allowed to develop her own method free from outside pressure. The Frainers of the Constitution recognized that this notion of "judicial independence" was vital to the effective functioning of the federal judiciary: "This independence of the judges is . . requisite to guard the Constitution and the rights of individuals [against legislative encroachments

90. Note, supra note 69 , at $1125 \&$ n.53. As Alexander Hamilton stated:

The want of a provision for removing the judges on account of inability has been a subject of complaint. But all considerate men will be sensible that such a provision would either not be practiced upon or would be more liable to abuse than calculated to answer any good purpose. The mensuration of the faculties of the mind has, I believe, no place in the catalogue of known arts. An attempt to fix the boundary between the regions of ability and inability would much oftener give scope to personal and party attachments and enmities than advance the interests of justice or the public good.

The Federalist No. 79, at 474 (A. Hamilton) (Mentor ed. 1961) (emphasis added).

91. Note, supra note 69 , at 1127.

92. Id.

93. See supra notes $62-81$, and accompanying text. 
and] from the effects of those ill humours which the arts of designing men, or the influence of particular conjectures, sometimes disseminate among the people." 94 The constitutional impeachment procedure as well as the "good behavior" provision of article III help protect the independence of the federal judiciary.

The Act threatens this protection of judicial independence. It may subject a judge to reprisal from colleagues who do not agree with her decisions. Under this regime, the politically astute judge might shape her rulings to conform with the political climate of her judicial circuit. The political views of a federal judge are constantly under scrutiny before, during, and soinetimes even after her tenure on the bench. This threat of censure might intrude unjustiflably on the independence of the federal judiciary. The compromise of judicial independence to the control of politically active federal judges is by no means a recent trend in this country's history. ${ }^{95}$ But the Act provides a formal mechanism for undermining the independence of federal judges.

Not only might the infusion of politics into the removal proceedings affect judicial behavior, it also may have a dramatic effect on the public's perception of an impartial judiciary. If the public believes that decisions of the federal judiciary are not rendered through impartial application of the law to the facts in a particular case, but rather are made by judges who take into consideration the possible political consequences that controversial decisions may have on their careers, the public's confidence in the judiciary as an impartial arbiter of justice will be undermined. The public perception of the integrity and impartiality of the judiciary is crucial to the enforceinent of judicial decisions. ${ }^{96}$ If the integrity of the federal judiciary is made questionable, the judgments of the federal courts nay become questionable as well.

94. The Federalist No. 78, at 527 (A. Hamilton) (Mentor ed. 1961).

95. The experience of Samuel Chase illustrates this: Opponents of his appointment to the Supreme Court, including Thomas Jefferson, were motivated primarily by political considerations. Later, during Jefferson's presidency, Chase was impeached by the House of Representatives, although he had violated no law. The charge against Chase was the expression of his political views while giving grand jury instructions. Chase's accusers charged that this constituted a "high crime or misdemeanor" pursuant to article II of the Constitution. Chase was eventually acquitted of all charges by the Senate, but the trial focused morc on the importance of an independent judiciary than on the actual charges levied against Chase. Stevens, Reflections on the Removal of Sitting Judges, 13 STETSON L. REV. 215, 219-20 (1984).

96. The intrusion of political considerations into the disciplinary procedures of the federal judiciary is at direct odds with the notion of separation of powers. It is hard to imagine how the judiciary can function truly as co-equal to the executivc and legislative branches when the judges cannot thoughtfully render their decisions without fear of political reprisal. 


\section{The Act Effectively Shifts the Responsibility for Judicial Discipline from Congress to the Courts}

The Act's provision for the de facto removal of federal judges relieves Congress' burden of overseeing the federal judiciary through the impeachment process. The Act provides a less time-consuming method of discipline, which the judiciary can administer entirely by itself. Although Congress has been reluctant to commence impeachment proceedings, ${ }^{97}$ the Act's removal process renders impeachment the discipline of last resort.

There are several reasons for congressional reluctance to utilize the impeachment process. First, members of the House of Representatives will usually find it politically unprofitable to spend a significant amount of time on such a lengthy, time-consuming process. ${ }^{98}$ To initiate such proceedings, several members of Congress have to view impeachment as appropriate and politically profitable. Second, Congress's inexperience at holding triallike proceedings makes the members of Congress hesitant to conduct them. ${ }^{99}$ Third, the impeachment procedure is an unwieldy mechanism. It is not an efficient means by which to discipline federal judges for misconduct. Finally, some representatives may feel that unless the conduct is criminal, some types of judicial malfeasance should be allowed in order to preserve the independence of the federal judiciary. ${ }^{100}$

Perhaps an even more revealing reason for congressional reluctance to impeach is the belief that the judiciary should keep its own house in order. As the District Court stated in Hastings, "The independence of the judiciary depends both on the courage and integrity of individual judges and on the public perception of the institution as fair, impartial and efficient. The judiciary has the inherent power to govern itself in a manner that will achieve these ends."101

Congress might believe that just as the bar regulates the conduct of its members, so should the judiciary regulate itself. Each of these reasons inay justify Congress's reluctance to utilize the iinpeachment process. None, however, justifies the removal procedure of the current Act. Unlike self-regulation by the bar, self-policing by the judiciary threatens the vital independence of individual judges. Contrary to the court's suggestion in Hastings, federal judges are stripped of their autonomy when their actions are subject to the scrutiny of their brethren.

97. See R. BERGER, supra note 89 , at 166-67.

98. Note, supra note 69, at 1139.

99. Id.

100. Id. at $1139-40$.

101. Hastings v. Judicial Conference of the United States, 593 F. Supp. 1371, 1380 (D.D.C. 1984), aff'd in part and vacated in part, 770 F.2d 1093 (D.C. Cir. 1985), cert. denied, 106 S. Ct. 3272 (1986). 
Impeachment may indeed be time consuming and unwieldy. But this inefficiency does not justify undermining impeachment in favor of an Act that authorizes de facto removal of federal judges for violations of a questionable standard. Convenience should not be the paramount consideration. The judicial system should be more concerned with maintaining the independence and integrity of the federal judiciary. ${ }^{102}$ Finally, there is no constitutional authority for Congress to create disciplinary procedures administered by the federal judiciary that result in de facto removal of judges. If Congress is reluctant to use the impeachment machinery explicitly provided for in the Constitution, then Congress should hesitate in giving the judiciary wide-reaching discretion to remove federal judges.

\section{IV}

\section{A Proposed Revision of the Judicial Councils Act}

The appearance of judicial propriety and the goal of judicial impartiality are both integral to the effective functioning of the federal courts. Because the impeachment process is an unwieldy and ineffective means of supervising and sanctioning federal judges, some mechanism short of impeachment is necessary to deal with judicial misconduct. The Judicial Councils Act is one attempt to provide such a mechanism, but it contains some serious flaws: It permits the de facto removal of federal judges, thus arguably violating the Constitution and undermining the intent of the Framers, and it injects politics into the removal process. Congressional reluctance to utilize the impeachment process does not justify the Act in its current form.

But the Act is susceptible of revisions. This Comment thus proposes a Revised Act, which concedes the necessity of a disciplinary procedure to complement impeachment, but attempts to avoid the shortcomings of the current Act. This Part sets out the proposed Revised Act and discusses the effects it would have on the present procedures for disciplining federal judges.

The Revised Act would contain the following provisions:

(1) Any person alleging that a federal judge has engaged in conduct that is unethical may file with the clerk of the court where the judge sits a complaint containing a brief statement of the facts constituting such conduct.

(2) Unethical conduct includes but is not limited to ex parte contacts with litigants, negotiating for employment with attorneys who are cur-

102. "Convenience and efficiency are not the primary objectives-or the hallmarks-of democratic government." INS v. Chadha, 462 U.S. 919, 944 (1983) (quoted in Hastings v. Judicial Conference of the United States, 770 F.2d 1093, 1111 (D.C. Cir. 1985) (Edwards, J., concurring)). 
rently litigating before the judge, and failure to excuse oneself from a case when a possible conflict of interest exists.

(3) Upon receipt of a complaint the clerk shall transmit the complaint to the chief judge of the circuit.

(4) After reviewing the complaimt the chief judge may either:

(a) dismiss the complaint if it is:

(i) not in conformity with paragraph 1 ,

(ii) directly related to the merits of a particular case, or

(iii) frivolous; or

(b) pass the complaint to a panel composed of federal judges from outside the accused judge's circuit.

(5) The panel will be composed of judges randomly selected from various circuits.

(6) Judges who are selected will serve one-year terms on the panel.

(7) The judicial panel shall conduct an extensive investigation and then file with the chief judge of the accused judge's circuit a report that includes its recommendations regarding possible sanctions.

(8) The judicial panel may recommend that the following action be taken:

(a) the accused judge should be censured or reprimanded by means of private communication;

(b) the accused judge should be censured or reprimanded by means of public pronouncement;

(c) the judicial panel should issue a public statement recommending that Congress institute impeachment proceedings against the accused judge; or

(d) the accused judge may be suspended for a period not exceeding six months, providing that Congress approves such suspension.

These proposed revisions make three significant changes in the current Act: (1) they provide that the panel evaluating a judge's conduct should be composed of judges from other circuits; (2) they permit suspension for a maximum of six months; and (3) they replace the current "prejudicial conduct" standard with the prevailing ethical standards for judicial conduct. Each of these changes will be discussed in turn.

First, under the Revised Act, all complaints filed against federal judges would be evaluated by a panel of federal judges who were not members of the accused judge's own judicial circuit. Judges from other circuits probably would not be as politically motivated as those from the accused judge's own circuit. The panels would be more politically diverse due to the random rotation of the panel positions among judges of all circuits. A panel of judges from other circuits would not know the accused judge as well as-and so presumably would have fewer personal biases than-the judges from the accused judge's own circuit.

Under the Revised Act, there would be less opportunity for any particular group of judges to hold ultimate sanctioning authority over their 
colleagues for an extended period of time because different judges would serve on the panel each year. Under the current system, federal judges have, in effect, life tenure to decide the fate of other judges in their circuits. Changing the composition of the panels every year would make it difficult for particular judges to control the outcomes. Judges participating in the panel would neither know each other nor be able to predict each other's responses, as they might under a system in which the same panel of judges meets year after year.

Second, under the Revised Act, there would be a six-month time limit imposed on a judge's suspension, and any suspension would have to be approved by Congress. As Judge Edwards pointed out in the Hastings case, a suspension that can last as long as fifteen years is the functional equivalent of removal. ${ }^{103}$ Six months should provide adequate time for the members of the judicial council to fully investigate and evaluate any alleged malfeasance.

Finally, under the Revised Act, the judicial council would continue to have the authority to investigate every complaint made against a judge. However, in contrast to the current Act, which allows judges to be suspended for "prejudicial" behavior, the Revised Act would allow suspension of a judge only if his behavior were improper when judged by ethical standards. By imposing more specific standards upon the judicial council, it is less likely that a judge would be brought up on vague charges because of her controversial political beliefs or unpopularity.

In determining whether a judge has behaved ethically, the judicial council should consider factors such as those elaborated in the American Bar Association's Code of Judicial Conduct. ${ }^{104}$ The types of judicial misconduct there covered include: (1) contact with litigants outside of the trial setting; (2) negotiating with attorneys involved in litigation before the judge about the prospect of the judge joining the law firm after leaving the bench; (3) failing to excuse oneself from litigation when one has a potential conflict of interest; and (4) failing to refrain from specified types of political activity inappropriate to one's judicial office. ${ }^{105}$ All of these actions would be forbidden under the ethical standards of the Revised Act.

The goal of establishing an effective mechanism for policing the federal judiciary and the goal of allowing federal judges to maintain their judicial independence are often at odds with each other. For the public to have confidence in the integrity of the federal judiciary, the proper

103. Hastings, 770 F.2d at 1108-09 (Edwards, J., concurring).

104. CODE OF Judiclal Conduct (1972).

105. The political activities in which the American Bar Association deems it inappropriate for a federal judge to engage include acting as a leader or holding office in a political organization and making speeches or publicly endorsing a candidate for political office. Id. Canon $7(\mathrm{~A})(\mathrm{i})$. 
balance between these two competing goals must be achieved. The current Act allows for too much compromise of a judge's independence, while the impeachment procedure is often unwieldy and rarely utilized. ${ }^{106}$

To maintain public confidence in the impartiality of the federal judiciary, politics must be left out of the procedures for removal. The current Act comes dangerously close to interjecting an overtly political element into the judicial misconduct proceedings because of its vague standard of "prejudice" and because of the discretionary power it places in the hands of the judge's colleagues on the bench. The presence of political biases in misconduct proceedings cannot be underestimated. Judicial independence is not merely a quaint rehc of constitutional interpretation; rather, it is the foundation upon which the public confidence in the federal judiciary is based. When political motives are allowed to play a role in disciphinimg individual federal judges, the independence of the federal judiciary as a whole is compromised. Political concerns must be excluded from the proceedings regulating judicial misconduct for the judiciary to maintain its rightful place as the equal of the executive and legislative branches of government.

The Revised Act here proposed retains a disciplinary procedure that complements the constitutional impeachment provisions while preserving the independence of individual federal judges from political interference.

\section{CONCLUSION}

It is anomalous to suggest that a member of the federal bench with lifetime tenure should be subject to removal for making politically unpopular decisions or holding politically unpopular views. The inherently political nature of appointment to the federal bench has made the lure of politics simply too enticing for some judges to pass up. While the political activity of federal judges raises serious issues concerning judicial ethics and propriety, a still more disturbing aspect of the politicized federal judiciary is the possibility that a judge may be effectively removed when her politics fall into disfavor among her judicial colleagues.

The current Act exposes a federal judge to censure or removal for holding unpopular political sentiments. Although the current Act addresses the very real problem of the administrative unwieldiness of the impeachment proceedings, it goes too far by allowing de facto removal of a federal judge by other members of the federal judiciary.

The Revised Act represents a compromise between the rarely utilized method of impeachment and the heavy-handed provisions of the

106. See supra notes $97-98$ and accompanying text. 
current Act. If such a compromise were enacted, the judiciary could keep its own house in order and still afford individual federal judges the freedom to decide unpopular cases and express unpopular political beliefs without fear of reprisal.

Drew E. Edwards*

\footnotetext{
* A.B. 1982, Stanford University; third-year student, Boalt Hall School of Law, University of California, Berkeley.
} 